\title{
PENDIDIKAN KARAKTER KAFFAH MELALUI PENGEMBANGAN BOARDING SCHOOL:
}

\section{SEBUAH ALTERNATIF}

\author{
Singgih Tri Sulistiyono*
}

\begin{abstract}
Abstrak
Pembangunan karakter bangsa merupakan sesuatu yang tidak bisa ditawar-tawar dalam rangka untuk memperbaiki krisis moralitas kebangsaan yang terjadi dewasa ini. Pendidikan karakter di sekolah merupakan salah satu upaya untuk pembangunan karakter bangsa secara keseluruhan. Dengan mengingat bahwa akar persoalah karakter bangsa bersumber pada kepribadian yang terbelah yang bermula dari adanya gap antara dunia pendidikan di sekolah dan dunia nyata dalam masyarakat maka diperlukan suatu sistem pendidikan yang kaffah yang mampu menciptakan manusia dengan kepribadian dan karakter yang utuh. Di samping itu pendidikan yang kaffah juga perlu diiringi dengan upaya pemerintah untuk menciptakan dan menegakkan hukum dalam masyarakat yang merefleksikan nilai-nilai luhur budaya dan karakter bangsa sebagaimana yang telah dirumuskan oleh kemendikbud. Model sekolah bording dengan penerapan pendidikan budaya dan karakter bangsa secara kaffah dapat dijadikan sebagai alternatif untuk mencetak generasi muda yang memiliki karakter yang diidealkan berdasarkan Pancasila dan nilai-nilai luhur budaya bangsa.
\end{abstract}

\section{Kata kunci: Pendidikan karakter, boarding school}

Kemerosotan kualitas kehidupan bersama sebagai suatu bangsa yang dikeluhkan oleh berbagai kalangan pada saat ini sebetulnya sudah muncul sejak tahun 1980-an. Pada waktu itu, berbagai sinyalemen adanya gejala yang akut mengenai 'merosotnya nasionalisme dan patriotisme', 'merosotnya sikap kepahlawanan', 'ancaman disintegrasi', terjadinya 'dekadensi moral', dan berbagai persoalan 'pelanggaran etika dan hukum', sudah mulai menjadi kekhawatiran banyak pihak. Adalah sangat ironis bahwa kekhawatiran tersebut muncul di tengahtengah upaya pemerintah Orde Baru yang pada waktu itu sedang menggalakkan pendidikan moral yang berupa penataran P4 (Pedoman Penghayatan dan Pengamalan Pancasila), Departemen Pendidikan dan Kebudayaan yang sedang gencar mengampanyekan matapelajaran PSPB (Pendidikan Sejarah Perjuangan Bangsa) dan Pendidikan Moral Pancasila (PMP), dan dalam kondisi perekonomian yang sedang mengalami 'boom'. Pada saat ini, sinyalemen-sinyalemen tersebut ternyata bukan hanya rangkaian kata-kata belaka tetapi betul-betul telah menjadi kenyataan. Republik Indonesia yang belum genap berusia tujuh dekade ini sedang mengalami berbagai konflik. Konflik-konflik politik yang mengancam persatuan dan kesatuan

* Singgih Tri Sulistiyono adalah Ketua DPW LDII Provisnsi Jawa Tengah, Dosen Jurusan Sejara Fakultas Ilmu Budaya Universitas Diponegoro Semarang 
bangsa Indonesia saat ini adalah masih belum tuntasnya persoalan disintegrasi bangsa. Apapun alasannya, konflik-konflik yang berpotensi meruntuhkan integrasi bangsa itu merupakan cermin kerapuhan nasionalisme dan patriotisme bangsa Indonesia. Balum lagi adanya berbagai konflik sosial yang sewaktu-waktu dapat mencuat ke permukaan.

Fenomena yang membuat hati menjadi 'miris' (tidak sekedar terusik) adalah adanya praktik-praktik korupsi dan 'mafianisme' hukum serta pelanggaran etika dan moral lainnya dalam kehidupan bersama sebagai sebuah komunitas bangsa yang jika tidak segera diantisipasi akan betul-betul menghacurkan diri sendiri. Belum lagi terjadinya tawuran antarpelajar yang menimbulkan kerusakan dan kematian juga masih sering terjadi. Krisis yang melanda moral masyarakat mengindikasikan bahwa pendidikan agama dan moral yang didapat di bangku pendidikan tidak berdampak terhadap perubahan perilaku manusia Indonesia. Bahkan yang terlihat adalah begitu banyak manusia Indonesia yang tidak koheren antara ucapan dan tindakannya. Hal ini kemungkinan besar berawal dari produk dunia pendidikan (Zubaidi, 2011: 2).

Dalam kondisi yang seperti itu, pendidikan moral yang kemudian terkenal dengan istilah pendidikan karakter (termasuk di dalamnya antara lain pelajaran
Agama, Sejarah, PPKn) diposisikan sebagai 'tertuduh'. Seringkali berbagai mata pelajaran tersebut dipandang telah gagal dalam pembangunan moral dan karakter bangsa. Orang sering mencemooh bahwa 'kegagalan' pendidikan moral dan karakter pada masa Orde Baru disebabkan oleh terlalu banyaknya kepentingan penguasa yang 'dititipkan' pada berbagai mata pelajaran yang dapat dikategorikan sebagai bagian dari pendidikan karakter.

Sebagai contoh adalah: hanya buku sejarah yang 'direstui' pemerintah saja yang boleh diedarkan dalam masyarakat. Dengan demikian ketika orang menyaksikan sendiri adanya kesenjangan antara perilaku pemerintah dengan substansi pendidikan karakter (mata pelajaran Sejarah, Agama, Pendidikan Moral Pancasila) maka yang terjadi bukanlan 'pemupukan' tetapi 'pembusukan' kehidupan bersama sebagai sebuah bangsa.

Ketika Orde Baru runtuh, 'kewibawaan' berbagai mata pelajaran yang dapat dikategorikan sebagai pendidikan karakter tersebut juga ikut merosot, karena semuanya dianggap bagian kebobrokan rezim itu. Di sini tampak dengan jelas bahwa materi pendidikan karakter yang kurang menyentuh akar kepribadian segenap bangsa kurang efektif untuk membangun karakter sebuah bangsa. Demikian juga pelajaran sejarah yang disampaikan dalam suasana kebohongan 
tidak bisa sepenuhnya dapat membangkitkan kesadaran sejarah atau historical consciousness (Ballard, 1971).

Kini, banyak orang yang merasa risau ketika berbagai persoalan internal yang terkait dengan national and character building mencuat keluar dan ternyata tidak mudah untuk diselesaikan. Apalagi kekuatan eksternal yang berupa gelombang globalisasi dan neoliberalisme semakin lama semakin agresif dalam mengikis karakter bangsa. Dalam sambutan pada peringatan Hari Pendidikan Nasional tanggal 2 Mei 2010 Presiden Susilo Bambang Yudhoyono mulai mencanangkan pendidikan karakter. Ia menyatakan pendidikan di Indonesia memiliki dua tujuan utama, yaitu: untuk mentransfer ilmu pengetahuan dan teknologi, dan untuk membangun karakter bangsa yang kuat (strong national character building).

Presiden juga menyatakan bahwa kemajuan pendidikan tidak boleh melupakan pembangunan karakter. Oleh karena itu Presiden melalui Kementerian Pendidikan Nasional akan meluncurkan 'Program Pendidikan Karakter'. Selanjutnya pemerintah menyusun Rencana Aksi Nasional (RAN) Pembangunan Karakter Bangsa Tahun 2010-2025 dan dan berbagai perangkat aturan lain termasuk Buku Pedoman Pendidian Karakter dan Budaya bangsa. Masih ada sementara orang yang masih pesimis apakah pendidikan karakter yang akan dan sedang dijalankan ini dapat mencapai hasil seperti yang diharapkan atau tidak. Jika pendidikan karakter diterapkan dalam kerangka paradigma pendidikan yang sama dengan periode sebelumnya, maka kemungkinan kegagalan akan di depan mata, sebab secara substansi, barangkali tidak ada yang baru antara pendidikan moral yang pernah dilaksanakan oleh pemerintah Indonesia sebelum Reformasi dengan pendidikan karakter saat ini. Paradigma pendidikan lama itu masih dapat dilihat dari beberapa aspek, misalnya keberhasilan pendidikan lebih banyak diukur dari segi kognitif daripada aspek afektif dan psikomotorik. Dalam hal ini UTS, UAS, UN, masih menjadi tolok ukur utama keberhasilan pendidikan.

Dengan demikian sebagian besar siswa dan orang tua siswa mengambil jalan pintas untuk mengambil les di berbagai lembaga bimbingan belajar untuk mempelajari soal dan jawabannya. Bahkan akhirnya guru juga menerapkan metode yang dugunakan oleh lembaga bimbingan belajar dalam kegiatan kurikuler di sekolah. Akibatnya adalah aspek pembinaan watak dan budi pekerti terabaikan dalam proses pendidikan. Bahkan secara tidak langsung siswa dibiasakan untuk bersikap instant dalam menyelesaikan masalah. Demikian juga sistem evaluasi pendidikan masih cenderung memakai instrumen yang mengesampingkan pola berpikir konvergen. 
Guru lebih menekankan pada kemampuan menguasai pengetahuan daripada memberi motivasi untuk belajar sehingga hasil akhir lebih penting daripada proses. Pada puncaknya, gelar kesarjanaan menjadi lebih penting daripada kompetensi untuk berinvensi dan berinovasi dalam memecahkan persoalan dalam rangka mencapai kemajuan masyarakat bangsa.

Dalam hubungan itulah, makalah ini akan mencoba untuk membahas salah satu alternatif model pendidikan karakter agar betul-betul dapat menghasilkan generasi muda Indonesia yang memiliki karakter sebagaimana yang diharapkan. Alternatif model pendidikan karakter itu adalah pendidikan karakter kaaffah atau yang dalam literatur Barat kurang lebih dapat disebut sebagai pendidikan holistik (holistic education). Untuk itu makalah ini akan mengawali pembahasannya terhadap sejarah pendidikan moral dan karakter di Indonesia beserta kelemahankelemahannya. Setelah itu, makalah ini akan membahas tentang konsep pendidikan karakter kaffah atau holistik beserta kemungkinan penerapannya di Indonesia sebagai sebuah alternatif.

Menilik Sejarah Pendidikan Karakter di Indonesia: dari Zaman Bung Karno hingga Pak Harto

Sebetulnya pendidikan karakter diperlukan bukan hanya ketika sebuah bangsa sedang mengalami banyak persoalan moralitas dan persoalan-persoalan krusial lainnya seperti yang dialami Indonesia pada saat ini. Pendidikan karakter secara kontinyu mutlak diperlukan oleh sebuah bangsa jika bangsa itu menginginkan untuk melanjutkan eksistensinya. Politikus pertama yang menyadari pentingnya pendidikan karakter, khususnya karakter kebangsaan dan nasionalisme serta patriotisme adalah Maximilien François Marie Isidore de Robespierre (6 May 1758 28 July 1794) seorang tokoh garis keras dalam Revolusi Perancis.

Ia pernah mengatakan: 'The nation has the right to bring up its children; we cannot confide this trust to family pride and individual prejudice' (Birch: 1989). Jadi sesungguhnya negara atau pemerintah lah yang memiliki kewajiban utama untuk melaksanakan pendidikan karakter kebangsaan dari setiap warga negaranya, karena hal itu akan menentukan masa dengan negara itu sendiri.

Sudah barang tentu corak pendidikan karakter bangsa yang dilakukan oleh negara bergantung terutama kepada dasar ideologi atau setidak-tidaknya kepentingan pemerintah yang sedang berkuasa. Di dalam sejarah Indonesia sendiri, ideologi dan kepentingan pemerintah silih berganti dan memiliki kecenderungan dan nuansa yang berbeda-beda. Pada masa akhir pemerintahan kolonial Belanda yang mulai 
dikendalikan oleh kaum liberal, pendidikan moral ataupun pendidikan karakter tidak diberikan secara khusus. Pendidikan agama Nasrani yang pada masa VOC masih sering dilaksanakan di sekolah, mulai dilarang.

Pemerintah kolonial menerapan kebijakan untuk melaksanakan pendidikan yang netral dari agama. Pendidkan diarahkan untuk memenuhi kebutuhan pasar tenaga kerja dalam kaitannya dengan bisnis kaum kapitalis di Hindia Belanda (Nasution: 1994). Sementara itu praktik pembangunan moral dilakukan melalui peraturan-peraturan sekolah yang mengatur perilaku siswa. Peraturanperaturan ini yang akan mampu membentuk karakter siswa seperti sikap disiplin, rasional, kritis, dan sebagainya.

Meskipun pendidikan model Barat yang diterapkan oleh pemerintah Hindia Belanda didasari atas filsafat rasionalisme dengan semangat liberalisme yang mestinya juga menghargai hak asasi manusia dan hak-hak individu, namun dalam praktiknya semangat diskriminasi dalam masyarakat kolonial masih sangat menonjol. Kesempatan pendidikan masih didasarkan atas status dan ras sesuai dengan dasar hukum Hindia Belanda yang membagi warga negaranya menjadi tiga golongan besar yaitu golongan Eropa atau orang yang dipersamakan dengannya (Europeanen en gelijkgesteld), Timur Asing (Vreemde Oosterlingen) dan Pribumi (Inlanders).
Hanya anak-anak dari golongan tertentu yang diperbolehkan mengenyam pendidikan formal dengan baik.

Sementara itu anak-anak masyarakat biasa tidak memiliki kesempatan yang luas untuk memperoleh pendidikan yang baik. Untuk meneguhkan perbedaan-perbedaan dalam masyarakat kolonial, pendidikan juga diselenggarakan dengan dasar kebudayaan dari masing-masing golongan penduduk, misalnya sekolah-sekolah di Jawa memiliki kurikulum yang mengajarkan kebudayaan dan bahasa Jawa. Demikian juga sekolahsekolah untuk keturunan orang Cina juga mengajarkan bahasa dan budaya Cina. Hanya sebagian kecil saja siswa-siswa pribumi (anak-anak amtenar) yang memiliki kesempatan bersekolah di sekolah-sekolah untuk orang Eropa. Pengajaran budaya ini akan memperkuat identitas dan kesadaran masing-masing siswa berdasarkan status dan rasnya yang sangat diskriminatif.

Ini juga dimaksudkan agar orangorang pribumi dapat menerima kedudukannya yang rendah sebagai inlanders, yang seolah-olah sudah ditakdirkan untuk melauani kepentingan orang-orang Belanda. Demikian juga sistem ini juga memberikan kesadaran kepada siswa-siswa Eropa untuk merasa lebih tinggi dari orang-orang pribumi dan timur asing. Jadi sistem pendidikan pada waktu itu memberikan kemungkinan bagi 
keberlanjutan struktur masyarakat kolonial yang diskriminatif.

Pada masa kolonial Belanda memang sudah diajarkan pelajaran sejarah, baik sejarah Negeri Belanda sendiri maupun sejarah Nederland Indie (Hindia Belanda) (Nasution, 1994: 131). Pelajaran sejarah juga dimaksudkan untuk membangun kesadaran bahwa sejarah Hindia Belanda adalah bagian dari sejarah Belanda. Dengan demikian akan timbul kesadaran bagi masyarakat pribumi untuk menerima hal itu sebagai sesuatu yang tidak bisa dihindari. Buku sejarah yang sangat penting pada waktu itu adalah karya F.W. Stapel (1938) yang berjudul Geschiedinis van Nederlands Indie.

Dengan melihat bahwa sistem pendidikan yang diterapkan oleh pemerintah kolonial Belanda yang bersifat diskriminatif dan bernuansa melanggengkan dominasi dan hegemoni penjajahan, maka beberapa organisasi pergerakan nasional berusaha untuk mengembangkan pendidikan sendiri seperti Taman Siswa, Muhammadiyah, NU, dan sebagainya. Di samping itu juga banyak tokoh yang berinisiatif mengembangkan sekolah seperti Imam Syafi'i di Kayutanam Sumatra, Kartini di Rembang, Dewi Sartika di Jawa Barat dan sebagainya (Djohan Makmur, dkk, 1993: 84-99). Dengan mengembangkan lembaga pendidikan itulah mereka tidak hanya mengajarkan ilmu pengetahuan dan ketrampilan modern tetapi juga membangun karakter sebagai kelompok komunitas yang beradab yang memiliki harga diri. Dengan kesadaran yang seperti inilah pendidikan Barat yang diberikan kepada beberapa tokoh nasional justru menjadi bumerang bagi pemerintah kolonial Belanda. Pelajaran sejarah Hindia Belanda yang diterima Sukarno akhirnya memberikan kesadaran kepadanya bahwa bangsa Indonesia dulu pernah jaya, dan sekarang (zaman kolonial) dalam keadaan terjajah, serta dia memiliki harapan untuk berjaya kembali di masa yang akan datang.

Apa yang bisa dikategorikan sebagai pendidikan karakter banrangkali berkembang dengan pesat pada zaman pemerintahan pendudukan Jepang, 19421945. Oleh karena situasi perang Pasifik yang menuntut dukungan dari masyarakat pada daerah-daerah yang direbutnya dari kolonialis Barat, pemerintah pendudukan Jepang berusaha untuk melakukan propaganda.

Dalam hal ini pedidikan yang dikembangkan di daerah-daerah pendudukan juga dimanfaatkan untuk propaganda dengan membangun moralitas siswa. Pendidikan karakter yang dikembangkan Jepang didasarkan atas basis filosofi Hakko Ichi-u. Konsep ini mengacu kepada gambaran mengenai dunia yang berada di bawah pimpinan Jepang. Dalam hal ini rakyat Indonesia harus mendukung 
saudara tua (Jepang) untuk membangun Asia Timur Raya untuk kemakmuran bersama. Indonesia baru akan tercapai jika bekerjasama dengan Jepang.

Oleh sebab itu masyarakat Indoneia harus bersumpah untuk setia kepada Tenno Heika. Aspek-aspek pendidikan karakter yang sangat membekas bagi para siswa di masa selanjutnya antara lain sikap egalitarian (sistem status yang hierarkhis zaman Belanda dihancurkan), sikap antibudaya Barat, semakin berkembangnya nasionalisme dan patriotisme di kalangan rakyat secara umum melalui penggunaan bahasa Indonesia di sekolah dan kantor serta latihan semi militer untuk menghadapi tentara Sekutu. Beberapa praktik pendidikan zaman Jepang yang masih ditiru dengan berbagai modifikasi pada masa setelah kemerdekaan Indonesia antara lain: setiap pagi sebelum pelajaran mulai diadakan upacara dengan menyanyikan lagu kebangsaan (Kimigayo), melakukan senam pagi (taisyo), dan mengibarkan bendera dan menghormat Tenno Heika serta mengucapkan sumpah setia kepada sang kaisar. Pada waktu tertentu siswa juga melakukan kegiatan kinrohhosyi (atau kerja bakti untuk sekolah dan lingkungannya).

$\begin{array}{lcrr}\text { Pada } & \text { masa } & \text { kemerdekaan } & \text { corak } \\ \text { pendidikan } & \text { Indonesia } & \text { masih } & \text { banyak } \\ \text { dipengaruhi } & \text { oleh } & \text { sistem } & \text { yang } \\ \text { dikembangkan Jepang } & \text { dalam kaitannya } \\ \text { dengan pendidikan karakter sesuai dengan }\end{array}$

situasi revolusi. Basis filosofi dari sistem pendidikan yang dikembangkan pada waktu itu adalah ideologi negara yaitu Pancasila dengan sendi-sendi agama dan kebudayaan bangsa (Sjamsuddin, 1993: 10). Dalam suasana revolusi, kesempatan memperoleh pendidikan tidak terjadi lagi sebagaimana zaman penjajahan Belanda, tetapi prinsipnya seperti zaman Jepang yaitu 'pendidikan untuk semua'. Selama periode revolusi, tujuan utama pendidikan pada waktu itu adalah untuk mengembangkan semangat nasionalisme dan patriotisme untuk mempertahankan kemerdekaan dari agresi Belanda. Hal ini terkait dengan suasana revolusi di mana anak-anak sekolah sejak usia 14 tahun banyak yang meninggalkan sekolah untuk mengangkat senjata yang tergabung dalam TRIP (Tentara Republik Indonesia Pelajar).

Perkembangan yang menarik terjadi pada periode setelah pasca revolusi kemerdekaan. Selama periode demokrasi liberal (1950-1957) pelaksanaan pendidikan didasarkan pada Undangundang No. 4 Tahun 1950 yang kemudian disempurnakan dengan UU No. 12 Tahun 1954. Dalam undang-undang itu dijelaskan dasar-dasar filosofis dan moral pelaksanaan pendidian di Indonesia: "Pendidikan dan pengajaran berdasarkan atas azas-azas yang termaktub dalam Pancasila, UUD Negara Republik Indonesia dan atas kebudayaan kebangsaan Indonesia". Tujuan pendidikan 
dan pengajaran adalah membentuk manusia susila yang cakap dan warga negara yang demokratis serta bertanggungjawab tentang kesejahteraan masyarakat dan tanah air (Sjamsuddin, 1993: 15). Dalam hal ini pendidikan karakter ditumpukan antara lain dengan pendidikan agama yang pelaksanaannya diatur dalam Peraturan Bersama antara Menteri Pendidikan, Pengajaran, dan Kebudayaan dan Menteri Agama pada tahun 1951. Selain itu sekolahsekolah juga diberi kesempatan untuk mengajarkan budi pekerti kepada siswa.

Setelah Indonesia memasuki periode Demokrasi Terpimpin

(1957-1965), pengaruh haluan politik pemerintah sangat jelas memberikan pengaruh kepada pelaksanaan pendidikan karakter. Seperti diketahui pelaksanaan Demokrasi Terpimpin memberikan peran yang sangat aktif kepada Presiden Sukarno untuk mempimpin dan mengatur pemerintahan. Dalam hal ini Presiden Sukarno melontarkan konsep politik yang terkenal dengan nama Manipol/USDEK yang merupakan akronim dari Manifesto politik / Undang-Undang Dasar 1945, Sosialisme Indonesia, Demokrasi Terpimpin, Ekonomi Terpimpin, dan Kepribadian Indonesia. Manipol/USDEK dijadikan sebagai haluan negara yang harus dijunjung tinggi, dipupuk, dan dijalankan oleh semua bangsa.

Pada waktu itu Pancasila dan Manifesto Politik-USDEK dipandang merupakan satu kesatuan. Jika Pancasila merupakan azas filosofis, maka Manipol/USDEK ditempatkan sebagai azas operasional. Haluan politik pemerintah ini tentu saja juga sangat berpengaruh terhadap dunia pendidikan. Pada waktu itu rumusan tujuan pendidikan adalah untuk menanamkan jiwa yang memiliki kepeloporan dalam membela dan mengembangkan Manipol/USDEK. Berbeda dengan periode sebelumnya (periode revolusi kemerdekaan dan demokrasi liberal), pada periode ini pendidikan karakter mulai diterapkan secara progresif. Pada waktu itu diselenggarakan matapelajaran Civic yang menjadi salah satu matapelajaran utama di setiap jenjang pendidikan. Ajaran-ajaran Manipol/USDEK menjadi materi utama dalam matapelajaran ini. Bahkan pada jenjang pendidikan tinggi, pendidikan ditujukan untuk membangun manusia yang memiliki semangat Pancasila dan mendukung pembentukan masyarakat Indonesia yang sosialistik, adil, dan makmur baik spiritual maupun material (Undangundang No 22/ 1961 (Law No. 22/1961)dalam:http://www.theceli.com/d okumen/produk/1961/22-1961.htm).

Dengan terjadinya pergantian pemerintahan dari Presiden Sukarno ke Presiden Suharto sejak tahun 1966, corak pendidikan juga mengalami perubahan. Dalam Tap XXVII /MPRS/1966 ditetapkan bahwa tujuan pendidikan nasional adalah 
untuk menghasilkan manusia Pancasila sejati. Dalam hal ini pendidikan harus mampu: a) mempertinggi mental-moralbudi pekerti dan memperkuat keyakinan agama, b) mempertinggi kecerdasan dan ketrampilan, dan c) mengembangkan fisik yang sehat dan kuat (Sjamsuddin, 1993: 82).

Perubahan suasana politik juga mendorong perubahan di bidang kurikulum. Kurikulum baru telah berhasil ditetapkan pada tahun 1968. Matapelajaran Civic diganti dengan Pendidikan Kewarganegaraan yang di dalamnya mengandung unsur pengetahuan sejarah, geografi, dan pengetahuan kewarganegaraan. Selanjutnya pada Kurikulum 1975, matapelajaran Civic dipecah menjadi dua yaitu PMP (Pendidikan Moral Pancasila) dan IPS (Ilmu Pengetahuan Sosial). Pendidikan Kewarganegaraan masuk ke dalam PMP, sedangkan sejarah dan geografi masuk ke dalam IPS. Untuk memperkuat pendidikan karakter kebangsaan maka pemerintah Presiden Suharto menyelenggarakan Penataran P4 (Pedoman Penghayatan dan Pengamalan Pancasila) yang wajib diikuti bukan hanya para siswa tetapi juga segenap elemen masyarakat.

\section{Menelisik Konsep Dasar Pendidikan Karakter di Zaman Reformasi}

$$
\text { Dengan runtuhnya pemerintah }
$$

Presiden Suharto, mata pelajaran PMP dan
Penataran P4 pun juga runtuh. Akibatnya Pemerintah Reformasi mengalami krisis pendidikan karakter. Bahkan Pancasila sebagai dasar dan ideologi negara juga sudah jarang disebut-sebut lagi oleh para pejabat. Berbagai persoalan moral bangsa juga belum menunjukkan perbaikan yang signifikan. Baru tahun 2010 Presiden SBY berkeinginan untuk menerapkan pendidikan budaya dan karakter bangsa atau sering disebut pendidikan karakter saja.

Pelaksanaan pendidikan karakter terutama didasarkan atas Undang-Undang Republik Indonesia nomor 20 tahun 2003 tentang Sistem Pendidikan Nasional (UU Sisdiknas) yang yang mengamanatkan bahwa:

"Pendidikan nasional berfungsi mengembangkan dan membentuk watak serta peradaban bangsa yang bermartabat dalam rangka mencerdaskan kehidupan bangsa, bertujuan untuk berkembangnya potensi peserta didik agar menjadi manusia yang beriman dan bertakwa kepada Tuhan Yang Maha Esa, berakhlak mulia, sehat, berilmu, cakap, kreatif, mandiri, dan menjadi warga negara yang demokratis serta bertanggung jawab".

Tujuan pendidikan nasional itu merupakan rumusan mengenai kualitas 
manusia Indonesia yang harus dikembangkan oleh setiap satuan pendidikan. Oleh karena itu, rumusan tujuan pendidikan nasional menjadi dasar dalam pengembangan pendidikan budaya dan karakter bangsa.

Dalam buku Pedoman Pendidikan Budaya dan Karakter Bangsa disebutkan bahwa tujuan pendidikan budaya dan karakter bangsa adalah: 1) mengembangkan potensi kalbu/nurani/afektif peserta didik sebagai manusia dan warganegara yang memiliki nilai-nilai budaya dan karakter bangsa; 2) mengembangkan kebiasaan dan perilaku peserta didik yang terpuji dan sejalan dengan nilai-nilai universal dan tradisi budaya bangsa yang religius; 3) menanamkan jiwa kepemimpinan dan tanggung jawab peserta didik sebagai generasi penerus bangsa; 4) mengembangkan kemampuan peserta didik menjadi manusia yang mandiri, kreatif, berwawasan kebangsaan; dan 5) mengembangkan lingkungan kehidupan sekolah sebagai lingkungan belajar yang aman, jujur, penuh kreativitas dan persahabatan, serta dengan rasa kebangsaan yang tinggi dan penuh kekuatan (dignity).

Adapun nilai-nilai yang dikembangkan dalam Pendidikan Budaya dan Karakter Bangsa terutama bersumber dari agama, Pancasila, budaya, dan UU Sisdiknas. Dari empat sumber nilai itulah

kemudian

Kemendiknas mengembangkannya menjadi 18 nilai yang diupayakan dapat diinnternalisasikan ke dalam diri peserta didik sehingga menjadi karakter mereka. Nilai dan deskripsi nilai Pendidikan Budaya dan Karakter Bangsa yang dikembangkan oleh Kemendiknas adalah sebagai berikut:

Apa yang membedakan antara pendidikan moral dan pendidikan karakter pada masa-masa sebelumnya dengan pendidikan karakter saat ini adalah bahwa secara prinsip pendidikan budaya dan karakter bangsa tidak dimasukkan sebagai mata pelajaran atau pun pokok bahasan tersendiri tetapi terintegrasi ke dalam mata pelajaran yang ada, penekanan pada pengembangan diri, dan penciptaan budaya sekolah. Oleh sebab itu sangat penting bagi sekolah untuk mengintegrasikan nilai-nilai yang ingin disosialisasikan dan diinternalisasikan dalam pendidikan budaya dan karakter bangsa ke dalam Kurikulum Tingkat Satuan Pendidikan (KTSP), Silabus dan Rencana Program Pembelajaran (RPP), kegiatan ekstra kurikuler, dan penciptaan budaya sekolah yang kondusif.

Dalam hal ini sekolah harus mengembangkan strategi pembelajaran agar peserta didik mengenal dan menerima nilai-nilai budaya dan karakter bangsa sebagai milik mereka dan bertanggung jawab atas keputusan yang diambilnya melalui tahapan mengenal pilihan, menilai pilihan, menentukan pendirian, dan 
selanjutnya menjadikan suatu nilai sesuai dengan keyakinan diri. Dengan demikian peserta didik belajar melalui proses berpikir, bersikap, dan berbuat. Ketiga proses ini dimaksudkan untuk mengembangkan kemampuan peserta didik dalam melakukan kegiatan sosial dan mendorong peserta didik untuk melihat diri sendiri sebagai makhluk sosial.

Pemerintah melalui Kemendikbud juga mengintroduksikan beberapa prinsip yang digunakan untuk pengembangan pendidikan budaya dan karakter bangsa di lembaga pendidikan, yaitu: 1) berkelanjutan, 2) melalui semua mata pelajaran, pengembangan diri, dan budaya sekolah, 3) Nilai tidak diajarkan tetapi dikembangankan, 4) proses pendidikan dilakukan peserta didik secara aktif dan menyenangkan.

Prinsip berkelanjutan mengandung makna bahwa pengembangan nilai-nilai budaya dan karakter bangsa merupakan sebuah proses panjang, dimulai dari awal peserta didik masuk sampai selesai dari suatu satuan pendidikan. Sebetulnya, proses tersebut dimulai dari kelas 1 SD atau tahun pertama dan berlangsung paling tidak sampai kelas 9 atau kelas akhir SMP. Pendidikan budaya dan karakter bangsa di SMA adalah kelanjutan dari proses yang telah terjadi selama 9 tahun.

Sementara itu prinsip ke dua mensyaratkan bahwa proses pengembangan nilai-nilai budaya dan karakter bangsa dilakukan melalui setiap mata pelajaran, dan dalam setiap kegiatan kurikuler dan ekstrakurikuler.

Prinsip ke tiga mengandung pengertian bahwa materi nilai budaya dan karakter bangsa bukanlah bahan ajar atau pun pokok bahasan yang diajarkan secara khusus kepada peserta didik. Dalam hal ini materi yang diajarkan dalam berbagai mata pelajaran harus digunakan digunakan sebagai media untuk mengembangkan nilainilai budaya dan karakter bangsa. Oleh karena itu, pendidik tidak perlu mengubah pokok bahasan yang sudah ada, tetapi menggunakan materi pokok bahasan itu untuk mengembangkan nilai-nilai budaya dan karakter bangsa. Demikian juga pendidik tidak perlu mengembangkan proses belajar khusus untuk mengembangkan nilai budaya dan karakter bangsa.

Dalam hal ini semua kegiatan pembelajaran dapat digunakan untuk mengembangkan kemampuan dalam ranah kognitif, afektif, dan psikomotor. Dalam konteks prinsip ini, nilai-nilai budaya dan karakter bangsa tidak perlu ditanyakan dalam ujian. Namun demikian, peserta didik harus memahami dan mengamalkan nilainilai yang sedang mereka internalisasikan.

Prinsip ke empat mensyaratkan bahwa proses pendidikan nilai budaya dan 
karakter bangsa dilakukan oleh peserta didik sendiri dan bukan oleh pendidik. Dalam hal ini prinsip "tut wuri handayani" perlu diterapkan oleh pendidik dalam proses pembelajaran. Sudah barang tentu prinsip ini tidak bisa terlaksana dengan baik kecuali dalam suasana belajar yang menyenangkan.

Media Internalisasi dan Sosialisasi Nilainilai Budaya dan

\section{Karakter Bangsa}

Kemendikbud telah mencanangkan bahwa perencanaan dan pelaksanaan pendidikan budaya dan karakter bangsa dilakukan oleh komunitas civitas academika sekolah yang terdiri dari kepala sekolah, pendidik, tenaga kependidikan secara bersama-sama sebagai suatu komunitas pendidikan. Sebagaimana telah disinggung sebelumnya bahwa sosialisasi dan internalisasi nilai-nilai budaya dan karakter bangsa ini diterapkan dalam kurikulum melalui kegiatan kurikuker dan ekstrakurikuler yang mencakup aspek pengembangan diri, aspek kurikuler, dan aspek budaya sekolah.

\section{Aspek Pengembangan Diri}

Dalam Buku Pedoman Pendidikan Budaya dan karakter bangsa dijelaskan bahwa aspek pengembangan diri dilaksanakan dalam kegiatan sehari-hari di sekolah melalui kegiatan rutin, kegiatan spontan, keteladanan, dan pengodisian. Contoh kegiatan rutin antara lain berbagai upacara di sekolah, pemeriksaan kebersihan badan (kuku, telinga, rambut, dan lain-lain) setiap hari Senin, beribadah bersama atau shalat bersama setiap dhuhur (bagi yang beragama Islam), berdoa waktu mulai dan selesai pelajaran, mengucap salam bila bertemu pendidik, tenaga kependidikan, atau teman dan sebagainya.

Sementara itu kegiatan spontan dilakukan secara spontan pada saat itu juga. Kegiatan ini berupa tindakan untuk mengingatkan dan mengoreksi kepada siswa yang sedang melakukan pelanggaran peraturan dan etika sekolah. Dengan demikian para siswa segera mengetahui bahwa perbuatan yang dilakukannya merupakan tindakan yang tidak sesuai dengan karakter moral bangsa. Sebaliknya perilaku siswa yang sedang melakukan perbuatan baik mendapatkan pujian dan apresiasi seperti ketika siswa mendapat nilai yang tinggi, menolong temantemannya, tekun membaca buku di perpustakaan, berani menolak ajakan teman untuk melakukan perbuatan yang melanggar norma dan etika sekolah, dan lain-lain.

Perilaku sehari-hari yang juga sangat penting adalah keteladanan sikap dan perilaku yang diberikan oleh pendidik dan tenaga kependidikan sehingga dapat menjadi panutan bagi para peserta didik, misalnya berbicara sopan, menghargai sesama guru dan tenaga kependidikan, disiplin, berpakaian rapi, membuang 
sampah pada tempatnya, dan sebagainya. Untuk mempersiapkan suasana keseharian yang kondusif sesuai dengan tuntutan pendidikan budaya dan karakter bangsa maka pihak sekolah juga harus melakukan pengondisian, yaitu menyediaan prasarana dan sarana yang memadai misalnya ketersediaan tempat sampah yang memadai, toilet yang higienis, taman sekolah yang indah, dan sebagainya.

\section{Aspek Kurikuler}

Dalam pendidikan budaya dan karakter bangsa, posisi semua mata pelajaran dalam kurikum sangat penting karena pengembangan nilai-nilai pendidikan budaya dan karakater bangsa diintegrasikan dalam setiap pokok bahasan dari setiap mata pelajaran. Dengan demikian nilai-nilai budaya dan karakter bangsa harus tercantum dalam silabus dan RPP. Demikian juga guru harus mengembangkan strategi pembelajaran yang memungkinkan nilai-nilai budaya dan karakter bangsa tersebut bisa disosialisasikan dan diinternalisasikan dalam kegiatan krikuler.

\section{Aspek Budaya Sekolah}

Dalam hal ini budaya sekolah mencakup pola pikir dan pola sikap serta perilaku yang dianut oleh segenap civitas akademika dalam kehidupan sekolah. Dalam hal ini budaya sekolah harus dikembangkan dengan dasar 18 nilai karakter sebagaimana yang telah dirumuskan oleh Kemendikbud. Pengembangan budaya sekolah dilakukan di setiap kesempatan secara terus-menerus dan di setiap tempat baik di kelas maupun di luar kelas, termasuk di luar lingkungan sekolah ketika siswa melakukan kegiatan ekstra kurikuler di luar sekolah, seperti di museum, lokasi bencana alam, kampung kumuh, dan sebagainya.

\section{Akar Persoalan Pendidikan Karakter Bangsa}

\section{Lingkungan Belajar Ambivalen}

Pertanyaan yang sangat penting untuk dijawab adalah apakah sistem persekolahan yang pada umumnya sekarang berlaku di Indonesia bisa mengondisikan efektifitas pelaksanaan pendidikan karakter secara kaffah? Hal ini perlu dipertanyakan mengingat bahwa pelaksanaan pendidikan moral dan karakter bangsa selama ini telah menghiasi masa-masa sepanjang sejarah pendidikan modern di Indonesia sebagaimana yang telah dipaparkan pada bagian sebelumnya. Namun demikian apabila keberhasilan upaya pendidikan moral dan karakter bangsa itu diukur dari performance moral dan perilaku orangorang yang pernah 'makan sekolahan' atau kaum terdidik ketika memegang kekuasaan negara maka bisa dikatakan bahwa pendidikan moral dan karakter bangsa tersebut mengalami kegagalan. Hal itu dapat dengan sederhana dilihat dari perjalanan sejarah bangsa Indonesia yang diwarnai dengan konflik, pelanggaran etika moral dan hukum, korupsi, dekadensi moral dan rasa 
cinta tanah air yang menyebabkan image Indonesia di mata pergaulan internasional menjadi merosot.

Kegagalan pendidikan moral dan karakter selama ini tidak terutama disebabkan oleh buruknya rumusan kristalisasi nilai-nilai moral yang diajarkannya. Substansi bahan ajar pendidikan moral dan karakter bangsa selama ini sudah sangat baik sebagaimana yang diajarkan pada Pendidikan Moral Pancasila pada zaman pemerintahan presiden Suharto. Dengan demikian pertanyaannya adalah apa yang menjadi penyebab utama kegagalan pendidikan moral dan karakter kebangsaan selama ini? Dalam hal ini penyebab utama kegagalan tersebut adalah bahwa anak didik hidup dalam lingkungan sosial dan budaya yang berbeda antara di sekolah dengan di dalam masyarakat. Di sekolah para peserta didik diajari berbagai nilai ideal yang pada kenyataannya berbeda dengan apa yang terjadi dalam masyarakat.

Di dalam masyarakat seringkali siswa harus melihat kenyataan yang pahit mengenai pelanggaran etika, susila, moral, peraturan negara baik dalam kehidupan sosial maupun dalam kehidupan berbangsa dan bernegara dengan berbagai bentuknya seperti korupsi, kolusi, nepotisme, kriminalitas, prostitusi, ketidakadilan, perlawanan terhadap pemerintah pusat, dan sebagainya. Ini berarti bahwa para peserta didik menghadapi lingkungan pendidikan yang ambivalen antara lingkungan sekolah dan lingkungan sosial budaya dalam masyarakat. Padahal lingkungan sosial budaya dalam masyarakat merupakan unsur yang sangat penting dalam proses pendidikan yang bersifat kaffah. Barangkali pertanyaan yang muncul adalah lebih kuat manakah antara pengaruh pendidikan di sekolah (yang biasanya lebih banyak bersifat teoritik) dengan pendidikan yang berlangsung di dalam masyarakat yang biasaya lebih bersifat praksis.

Dalam sistem persekolahan yang kovensional, peserta didik menghabiskan waktu di lingkungan sekolah hanya sekitar seperempatnya saja dari waktu 24 jam yang mereka miliki yaitu dari pukul 07.00 pagi hingga 13.00 siang. Selebihnya mereka menghabiskan waktu di lingkungan masyarakat dan sisanya dalam keluarga. Dengan demikian mudah diperkirakan jika pengaruh lingkungan masyarakat lebih berperan membentuk kepribadian peserta didik daripada lingkungan sekolah. Bangunan karakter yang hendak didirikan oleh sekolah dalam diri peserta didik harus menghadapi gempuran badai yang lebih kuat di dalam masyarakat. Perkembangan teknologi komunikasi yang sangat pesat selama kurang lebih satu dekade terakhir ini juga sangat memperparah keadaan ketika pengaruh negatif dunia luar sekolah masuk dengan mudah dalam lingkungan sekolah 
melalui hand phone dan internet. Dalam menghadapi tantangan ini terdapat beberapa alternatif pemecahannya, antara lain: memperpanjang kehadiran peserta didik di lingkungan budaya sekolah, dan mengubah carut-marut budaya dalam lingkungan masyarakat menjadi lingkungan yang kondusif bagi pendidikan budaya dan karakter bangsa.

\section{Kepribadian Terbelah}

Salah satu sebab muncul dan berkembangnya persoalan-persoalan besar yang dihadapi oleh bangsa Indonesia saat ini mulai dari pelanggaran etika dan moral hingga pelanggaran hukum serta mulai membusuknya rasa keindonesiaan adalah berkembangnya kepribadian yang terbelah yang dialami oleh sebagian atau bahkan mungkin sebagian besar bangsa Indonesia. Berbagai peristiwa yang mencengangkan terjadi yang merefleksikan adanya kepribadian terbelah atau kepribadian ganda, misalnya seorang penegak hukum yang justru pada saat yang sama memanfaatkan kedudukannya untuk korupsi, seorang yang tampaknya sebagai ahli ibadah namun ternyata juga melakukan korupsi dan perbuatan maksiat lainnya.

Kepribadian ganda atau juga sering disebut juga kepribadian terbelah (Multiple Personality Disorder) merupakan suatu keadaan di mana kepribadian individu terpecah sehingga muncul kepribadian lain.
Kepribadian itu biasanya merupakan ekspresi dari kepribadian utama yang muncul karena kepribadian utama tidak dapat mewujudkan hal yang ingin dilakukannya. Bisa diartikan bahwa kepribadian ganda merupakan kondisi ketika beberapa pribadi yang sepenuhnya berbeda muncul dalam satu tubuh. Kondisi ini juga dikenal sebagai penyimpangan disasosiasi identitas.

Dalam term agama Islam kepribadian ganda ini merujuk kepada simptom yang ditampilkan oleh seseorang yang memiliki beberapa ciri orang munafik. Ketika bersama dengan orang-orang iman, orang yang berkepribadian ganda akan menyatakan diri dan menampilkan diri sebagai orang iman, namun bila berkumpul dengan orang kafir, dia juga akan berpikir, bersikap dan berperilaku sebagai orang kafir juga. Hal itu sesuai dengan firman Allah SWT:

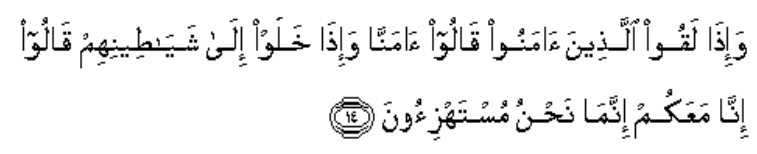

Artinya: "Dan bila mereka berjumpa dengan orang-orang yang beriman, mereka mengatakan: "Kami telah beriman". Dan bila mereka kembali kepada pemimpinpemimpin mereka, mereka mengatakan: "Sesungguhnya kami sependirian dengan kamu, kami hanyalah berolok-olok". Dalam khasanah budaya Jawa orang seperti ini sering diberi predikat sebagai orang yang 
bisa "mancala putra, mancala putri". Mereka bisa menjadi dermawan untuk memberikan amal jariyah pembangunan masjid, namun pada saat yang sama mereka juga seorang koruptor. Ada seseorang jika di rumah sebagai penyayang keluarganya, namun ketika di dalam masyarakat ia berubah menjadi orang yang kasar dan sadis. Demikian juga ada seseorang yang rajin beribadah namun juga melakukan apa yang dalam masyarakat Jawa disebut "Mo Limo" (madat, madon, minum, maling, main).

Oleh karena kemunafikan dan kepribadian ganda lahir dari proses pendidikan dan pembiasaan yang bersifat parsial (tidak utuh) maka diperlukan suatu sistem pendidikan yang bersifat holistik yang dalam istilah Islam disebut sebagai kaffah. Pertanyaannnya: benarkah sistem pendidikan yang berlangsung selama ini masih parsial? Jawabannya memang tidak bisa hitam-putih. Jika dicermati, konsep pendidikan budaya dan karakter bangsa yang sedang diintroduksikan oleh pemerintah SBY saat ini sudah mencerminkan adanya upaya untuk mengintegrasikan semua determinan yang menentukan keberhasilan pendidikan baik dari sisi materi, lingkungan, maupun pelaksananya.

Dari sisi materi, nilai-nilai yang hendak diinternalisasikan dan disosialisasikan oleh Pendidikan Budaya dan Karakter Bangsa sudah diintegrasikan ke dalam semua mata pelajaran yang ada. Dari sisi lingkungan atau pun budaya sekolah yang hendak dibangun melalui Pendidikan Buadaya dan Karakter Bangsa sudah mencerminkan adanya integrasi antara budaya di dalam kelas, dan lingkungan sekolah serta masyarakat di mana peserta didik akan melakukan kegiatan ekstra kurikuler. Demikian juga, secara konseptual para pelaksana Pendidikan Budaya dan Karakter Bangsa di sekolah juga sudah merupakan elemen yang komprehensif antara unsur pendidik dan tenaga kependidikan.

Namun demikian konsep seperti ini masih mengkawatirkan akan menghasilkan insan dengan kepribadian yang terbelah. Karena betapa pun komprehensifnya pendidikan di sekolah namun jika para peserta didik menghadapi suasana lain dalam masyarakat maka pendidikan karakter dan moral di sekolah tidak banyak memberikan dampak yang signifikan. Dengan demikian perlu konsep yang betulbetul mencerminkan pelaksanaan pendidikan yang bersifat holistik atau kaffah dalam rangka membentuk insan kamil atau manusia paripurna.

\section{Pendidikan Karakter Kaffah}

Untuk membangun insan kamil atau sering disebut sebagai manusia paripurna diperlukan pendidikan yang paripurna juga, 
yaitu pendidikan seara kaffah atau menyeluruh. Dalam teori pendidikan Barat, pendidikan yang bersifat kaffah ini barangkali mirip dengan konsep pendidikan holistik atau holistic education yang merupakan salah satu penjabaran dari filsafat holism di dunia pendidikan.

Filsafat holisme memandang bahwa sebuah sistem berfungsi sebagai sebuah keseluruhan dan fungsi sistem tersebut tidak dapat sepenuhnya dipahami sematamata dari masing-masing bagian dari sistem itu. Atau sebaliknya bagian-bagian dari sebuah sistem tidak dapat dipahami jika tidak ditempatkan dalam keseluruhan sistem. Keseluruhan sistem bukan merupakan penjumlahan dari bagaianbagian dari sistem tersebut dan keseluruhan sistem akan menentukan dinamika dari bagian-bagiannya.

Dalam filsafat pendidikan holisme atau filsafat pendidikan holistik dikembangkan premis bahwa setiap orang akan menemukan identitas, makna, dan tujuan hidupnya melalui interaksi di dengan lingkungannya sebagai sebuah keseluruhan yaitu: masyarakat, alam, dan nilai-nilai kemanusiaan seperti kasih sayang dan perdamaian. Pendidikan holistik bertujuan untuk membangkitkan kesalehan hidup yang intrinsik dan cinta yang penuh gairah untuk belajar pada diri peserta didik. Robin Ann Martin menyatakan bahwa secara umum perbedaan umum antara pendidikan holistik dari bentuk-bentuk pendidikan lain terletak pada tujuannya, perhatiannya terhadap pengalaman belajar, dan pentingnya menempatkan pendidikan dalam konteks nilai-nilai dasar kemanusiaan dalam lingkungan belajar (http://en.wikipedia.org/wiki /Holistic_education).

Dengan demikian pendidikan holistik merupakan pendidikan yang menyeluruh untuk membantu peserta didik untuk berkembang secara optimal sesuai potensi yang dimilikinya baik di bidang intelektual, emosional, sosial, fisik, seni, kreatifitas, dan spiritual. Proses pendidikan juga mencakup pengembangan ranah kognitif, afektif, dan psikomotor atau yang terkenal dengan konsep taksonomi Bloom. Dalam hal ini proses pendidikan akan mengambangkan tanggung jawab peserta didik baik secara personal maupun secara sosial.

Robin Ann Martin dan Scott Forbes ( 2004) membagi dua capaian dalam proses pendidikan holistik, yaitu ultimasi dan kearifan. Capaian ultimasi dapat mencakup religiusitas, psikologis, dan ketakterbatasan. Capaian religiusitas atau spiritualitas anak didik merupakan komponen penting dalam pendidikan holistik karena religiusitas menekankan pada interrelasi antara semua makhluk hidup dan penekanan pada harmoni antara "the inner life and outer life", antara hati dengan sikap dan tindakan. Dengan demikian pendidikan dalam capaian 
ini akan berfungsi untuk membuat individu menjadi tercerahkan atau "enlightened".

Sementara itu capaian psikologis mengacu pada aktualisasi diri (self actualization) di mana pendidikan harus memberikan kemungkinan kepada individu untuk berkembang sesuai dengan potensinya. Tidak ada kekurangan dalam diri anak didik, yang ada hanyalah perbedaan. Aspek capaian ketakterbatasan mengacu kepada prinsip bahwa pendidikan harus mengembangkan individu untuk mencapai tingkatan yang paling tinggi yang bisa dicapai oleh manusia yang tidak hanya mencakup aspek jasmaniah tetapi juga rohaniah.

Sementara itu capaian kearifan mencakup aspek freedom (kebebasan khususnya secara psikologis), Goodjudgement/ self-governance (mandiri), meta learning (setiap anak didik belajar sesuai dengan cara mereka sendiri), social ability (tidak sekedar belajar mengenai ketrampilan sosial, tetapi bisa mempraktekkan), refining values (mampu mengembangkan karakter), dan self knowledge (mampu mengembangkan aspek emosional

(http://en.wikipedia.org/wiki

/Holistic_education).

Dalam Islam misalnya untuk menjadi insan kamil harus memiliki komitmen untuk berislam secara kaffah. Dalam hal ini Islam mewajibkan para umatnya untuk memiliki kepribadian yang utuh sebagai orang iman yang melaksanakan segala sunatulloh seoptimal kemampuannya dan menjauhi segala larangan-Nya. Hal ini sesuai dengan perintah Alloh SWT:

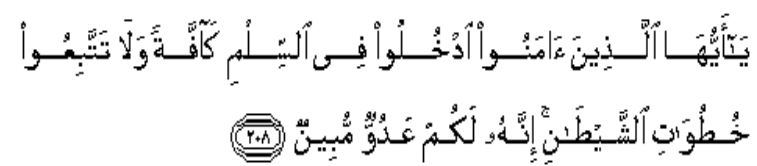

Artinya: "Hai Orang beriman masuklah kamu ke dalam islam secara keseluruhan, dan janganlah kamu turut langkah-langkah syaitan. Sesungguhnya syaitan adalah musuh yang nyata bagimu (QS Albaqarah: 208).

Menurut ayat tersebut orang yang berkepribadian utuh adalah orang yang mampu mengejawantahkan nilai-nilai luhur agama baik dalam pikir, sikap dan perilaku secara utuh dan konsisten. Sebaliknya orang yang tidak mampu menjadikan nilai-nilai agama dalam pikir, sikap, dan perilaku secara utuh dan konsisten akan menghadapi persoalan kepribadian ganda sebab ia akan mengambil nilai-nilai lain yang bertentangan dengan kaidah agama, yang berarti orang tersebut telah mengambil jalan syaitan yaitu jalan yang menyimpang dari grand narative dari kaidah agama.

Sudah barang tentu pengertian totalitas dan konsistensi dalam berkomitmen untuk berpola pikir, bersikap, dan berperilaku sesuai dasar-dasar agama memiliki pengertian yang luas. Dalam hal ini 
ada prinsip yang menyatakan bahwa untuk urusan keduniaan, apapun boleh dilakukan kecuali yang dilarang oleh Alloh SWT. Sebaliknya untuk urusan ibadah mahdoh berlaku prinsip: jangan melakukan apapun kecuali yang diperintahkan oleh Alloh SWT. Dengan demikian semua nilai-nilai budaya yang ada bisa dijalankan sejauh tidak bertentangan dengan nilai-nilai yang termaktub dalam dasar-dasar Agama Islam.

Para Alim Ulama besar sejak dulu bersepakat bahwa yang dimaksud Islam secara keseluruhan berarti Islam secara lahir dan bathin. Islam secara lahir berarti seseorang harus mampu melaksanakan apa yang tertuang dalam ketentuan ilmu Fiqih (Syari'at Islam). Pelaksanaan ilmu fiqih merupakan bentuk-bentuk peribadatan yang kasat mata seperti shalat, zakat, haji, tidak mencuri, tidak berzina dan sebagainya. Dari sini kemudian ditingkatkan kepada bentuk peribadatan bathin seperti ikhsan, tawadlu, mejaga hati, senantiasa berdzikir, dan sebagainya. Dengan memenuhi dua aspek tersebut, secara sederhana orang sudah bisa dikatakan Islam secara kaffah. Pengamalan Islam secara kaffah juga mencakup komitmen untuk menjalankan hukum dan nilai-nilai Islam secara keseluruhan baik yang mudah maupun yang sulit, baik yang mengenakkan maupun yang tidak mengenakkan, dan seterusnya. Jika orang Islam sudah bisa menjalankan nilai dan hukum Islam secara kaffah maka ia akan menjadi manusia yang 'sempurna' atau yang oleh kaum sufi disebut sebagai insan kamil.

Insan kamil ialah manusia yang sempurna dari segi wujud dan pengetahuannya. Kesempurnaan dari segi wujudnya ialah karena dia merupakan manifestasi sempurna dari citra Tuhan, yang pada dirinya tercermin nama-nama dan sifat Tuhan secara utuh. Adapun kesempurnaan dari segi pengetahuannya terkait dengan pengetahuan dan pemahamannya mengenai ilmu agama yang bersumber kepada Al Quran dan Al Hadits. Bagi para sufi, insan kamil merupakan manifestasi dari penampakan (madzhar) diri Tuhan paling sempurna, meliputi namanama dan sifat-sifat-Nya. Allah SWT memilih manusia sebagai makhluk yang memiliki keunggulan (tafadhul) atau ahsani taqwim (ciptaan paling sempurna) menurut istilah Alquran. Jadi jika kita ingin mencetak karakter siswa menjadi insan kamil/ manusia paripurna maka diperlukan pendidikan yang kaffah.

Dalam konteks keindonesiaan Pendidikan Karakter Kaffah dapat didefinisikan sebagai upaya terencana untuk menanamkan nilai-nilai luhur yang bersumber dari ajaran Islam (Al Qur'an dan Al Hadits), Pancasila, dan nilai-nilai luhur dari Kebudayaan Nasional dalam rangka membangkitkan kesadaran hati serta kemauan peserta didik untuk mengamalkan 
nilai-nilai luhur tersebut dalam kehidupan nyata sehari-hari. Sementara itu tujuan Pendidikan Karakter Kaffah dapat dirumuskan sebagai berikut: mengembangkan secara optimal potensi peserta didik menjadi individu berakhlakul karimah yang mampu membuat keputusan baik-buruk berdasarkan nilai-nilai luhur tersebut, memelihara apa yang baik dan mewujudkan kebaikan itu dalam kehidupan pribadi sehari-hari serta kehidupan bermasyarakat, berbangsa dan bernegara dengan ikhlas untuk mencari ridhlo Allah SWT.

Pendidikan kaffah adalah mendidikan yang menyeluruh (holistik) dan sekaligus terpadu (integrated) yang mencakup: 1) keseluruhan dan keterpaduan dalam pengembangan secara optimal aspek kognitif materi pendidikan dengan praktik (afektif dan psikomotor) kehidupan seharihari baik di lingkungan sekolah, keluarga, dan masyarakat. 2) Keseluruhan dan keterpaduan para pemangku kepentingan antara civitas akademika sekolah, orang tua/wali peserta didik, dan tokoh-tokoh masyarakat (ulama, umaro, tokoh masyarakat dan adat). 3) Keseluruhan dan keterpaduan antara pengembangan budaya yang mencerminkan nilai-nilai luhur di lingkungan sekolah, keluarga dan masyarakat.

Sistem Sekolah Boarding untuk Proses Pendidikan Karakter Kaffah
Pada bagian sebelumnya telah diulas bahwa salah satu faktor yang menyebabkan kegagalan pendidikan karakter di Indonesia bersumber dari adanya ambivalensi atau seringkali bahkan kontradiksi antara nilai yang dikembangkan di sekolah dengan di dalam masyarakat. Nilai-nilai yang disemai dan dikembangkan di sekolah seringkali terkontaminasi dalam budaya yang berkembang di dalam masyarakat. Salah satu upaya untuk mengatasi hal tersebut adalah dengan memperpanjang kehadiran peserta didik dalam lingkungan pendidikan yang kondusif di sekolah melalui penerapan sistem boarding school atau sekolah bording. Boarding school berasal dari dua kata yaitu boarding dan school. Boarding bisa diartikan sebagai pemondokan sedangkan school berarti sekolah. Dengan demikian secara harafiah boarding school dapat diartikan sebagai sekolah pemondokan. Dalam pengertian yang luas boarding school merupakan sekolah di mana semua siswa belajar dan tinggal di lingkungan sekolah bersama dengan semua atau sebagian pendidik dan/ atau tenaga kependidikan. Dalam pengertian yang lebih luas, pnegertian sekolah bording ini direduksi sebagai full-day school, yaitu sekolah yang jam pelajarannya sehari penuh dari pagi hingga sore. Pada sore dan malam hari para siswa pulang ke rumah orang tua masing-masing.

Dalam sejarah pendidikan di Indonesia konsep boarding school 
barangkali dapat diindentikkan dengan padepokan yang merupakan tempat pendidikan khusus di mana para siswa belajar dan tinggal di padepokan atau asrama bersama guru atau pendeta dan para cantrik yang merupakan semacam guru magang. Di dalam padepokan atau asrama inilah para siswa digodog untuk menjadi cendekiawan dan pemimpin di dalam masyarakat dan negara. Pada masa pengaruh agama Hindu di Jawa, para pejabat tinggi negara yang berasal dari kelompok ksatria biasanya digembleng dulu di dalam padepokan. Sistem pendidikan padepokan ini juga ditemukan dalam cerita pewayangan. Semasa anak-anak dan remaja, ksatria tangguh seperti Arjuna digodhok dalam pendidikan berbagai padepokan. Pada masa perkembangan agama Islam di Nusantara, sistem pemondokan atau asrama ini tidak dihapuskan tetapi justru dilestarikan dan dikembangkan, yaitu menjadi apa yang hingga sekarang disebut sebagai pondok pesantren. Di pondok pesantren ini, para siswa (santri) belajar dan tinggal bersama kyai dan ustad mereka.

Di Eropa, praktik mengirim anak-anak ke keluarga lain atau ke lembaga pendidikan sehingga mereka dapat belajar bersama juga sudah ada sejak ribuan tahun yang lalu. Setelah agama Nasrani berkembang di sana (terutama setelah memasuki Abad Pertengahan sekitar abad VI Masehi), banyak keluarga mengirim anak laki-laki untuk diajar oleh para pendeta baik di dalam gereja maupun dalam sebuah rumah tangga yang besar. Tradisi ini lah yang kemudian menjadi lembaga sekolah dan universitas di Eropa yang merupakan salah satu tenaga penggerak utama kemajuan negara-negara Barat.

Kekuatan sistem boarding school terletak pada kemungkinannya untuk mendidik para siswa secara kaffah, baik dari sisi alokasi waktu maupun dari sisi substansi kurikulum berserta strategi pembelajarannya. Dari sisi alokasi waktu, selama 24 jam setiap hari sekolah dapat menginternalisasikan dan menyosialisasikan nilai-nilai karakter ideal kepada seluruh siswa. Dalam waktu 24 jam setiap hari selama masa studi siswa dapat hidup dan berlatih serta mempraktikkan hidup dalam lingkungan budaya sekolah yang dirancang untuk kondusif bagi pendidikan. Dalam hal ini sekolah dapat merancang jadual yang sistematis dalam rentang waktu 24 jam sehari semalam dalam rangka untuk membentuk karakter siswa yang ideal baik dari sisi kognitif, afektif, dan psikomotor. Sekolah bisa merancang everyday-life activities para siswa mulai dari doa dan sholat malam (bagi sekolah boarding Islam), sholat subuh, pengajian, dan seterusnya hingga tidur malam setelah belajar.

Dari sisi substansi kurikulum dan strategi pembelajarannya, sekolah bording juga memiliki keleluasaan untuk memasukkan kurikulum yang 
diinginkannya baik kurikulum yang sejalan dengan kurikulum nasional maupun kurikulum tambahan yang terkait dengan pendidikan agama, moral, karakter, kepemimpinan, dan kompetensi soft skill lain sebagaimana yang dikembangkan oleh Kemendikbud melalui 18 nilai karakter yang ideal. Ketersediaan waktu 24 jam juga memungkinkan sekolah untuk menerapkan metode dan strategi pembelajaran yang efektif dalam rangka melakukan proses pembiasaan yang akan menjadi landasan bagi terbentuknya karakter siswa. Sudah barang tentu kunjungan ke keluarga dan masyarakat juga harus diagendakan agar siswa juga memiliki pemahaman dan conscience atau nurani yang prihatin kepada kehidupan masyarakat. Pada prinsipnya, pihak sekolah dapat memanfaatkan semua waktu siswa untuk proses pendidikan. Dengan sistem seperti ini, pendidikan yang kaffah dapat dijalankan dalam rangka membentuk manusia paripurna, manusia kaffah, atau pun manusia paripurna.

\section{Peran Pemerintah}

Untuk membangun dan mengembangkan sekolah bording tentu saja bukan merupakan usaha yang murah dan mudah. Namun demikian apapun hambatannya, pemerintah pada dasarnya merupakan pihak yang peling bertanggungjawab dalam pembinaan karakter bangsa untuk menjamin keberlangsungan bangsa dan negara itu sendiri. Sebetulnya jika pemerintah memandang perlu bahwa sistem sekolah bording dapat dijadikan sebagai media untuk mencetak generasi muda yang berkarakter kaffah maka tidak ada ruginya untuk mengembangkan sekolah-skolah konvensional menjadi sekolah bording dalam rangka menciptakan manusia Indonesia yang kaffah, menjadi insan Indonesia yang paripurna. Melalui sistem sekolah bording ini lah sosialisasi dan internalisasi 18 nilai karakter bangsa dapat dilakukan dengan baik.

Untuk memodifikasi sekolah-sekolah konvensional menjadi sekolah bording diperlukan penyiapan gedung sekolah dan asrama dengan segara perangkat dan fasilitas yang dibutuhkan, training guru dan tenaga kependidikan, kurikulum dan strategi pembelajaran, dan sebagainya. Upaya ini memang tidak ringan, namun sesuai dengan konstitusi bahwa negara lah yang memiliki kewajiban utama untuk menyelenggarakan pendidikan. Pendidikan yang berkualitas memang sangat mahal, namun akan sangat mahal lagi jika pengabaian pendidikan telah mengakibatkan keterbelakangan sebuah bangsa. Namun demikian jika pemerintah dengan berbagai alasan belum bisa melakukan hal tersebut maka peran masyarakat yang peduli terhadap pendidikan dan kemajuan bangsa sangat 
dibutuhkan. Oleh sebab itu perlu mendapatkan dukungan yang positif.

\section{Peran Swasta}

Selama ini sebagian besar sekolah bording diusahakan oleh pihak swasta. Memang di satu sisi memang hal ini bisa dilihat sebagai manifestasi besarnya perhatian dan partisipasi masyarakat dalam upaya untuk membangun kualitas sumberdaya manusia baik dari sisi intelektual maupun emosional. Namun demikian di sisi lain partisipasi yang sangat besar dari masyarakat tersebut juga menunjukkan lemahnya pemerintah dalam melaksanakan tanggungjawabnya di bidang penyelenggaraan pendidikan yang terbaik bagi generasi muda sebagaimana amanat konstitusi.

Salah satu faktor mengapa yayasan swasta justru bisa mengembangkan pendidikan yang holistik melalui sistem sekolah bording karena mereka memiliki keleluasaan dalam menarik dana dari orang tua yang menginginkan anaknya dididik dengan baik. Tidak jarang pula yayasan swasta menerima dana dari donatur tanpa melalui pertanggunjawaban yang ketat sehingga likuiditas penggunakan dana bisa cepat sesuai dengan tuntutan dinamika pendidikan. Sementara itu, pemerintah yang belum sepenuhnya memberikan prioritas utama pembangunan pendidikan selalu merasa keberatan untuk membiayai anggaran pendidikan yang ideal yang memang membutuhkan dana yang besar. Keterbatasan anggaran dan likuiditas sistem keuangan akhirnya menjadi kendala yang serius bagi penciptaan sistem pendidikan yang kaffah.

\section{Menciptakan Lingkungan Belajar dalam Masyarakat}

Sebagaimana dijelaskan di bagian depan bahwa lingkungan masyarakat sebetulnya merupakan sumber belajar yang sangat penting bagi siswa. Dengan belajar di dalam masyarakat, siswa dapat mengambil nilai-nilai yang akan dapat digunakan sebagai bekal untuk menjadi warga masyarakat yang baik. Namun demikian persoalan besar akan timbul jika masyarakat dinilai tidak lagi menjadi ruang belajar yang kondusif untuk mencetak generasi muda yang memiliki karakter yang diidealkan dalam dunia pendidikan. Bahkan banyak yang mengkawatirkan bahwa kehidupan nyata dalam masyarakat akan memberikan contoh-contoh yang tidak baik kepada generasi muda yang berupa berbagai pelanggaran terhadap nilai, etika, norma, dan undang-undang yang ada. Pengaruh masyarakat ini menjadi sangat besar ketika kepribadian siswa sendiri belum terbentuk melalui pendidikan dalam keluarga dan di dalam sekolah. Ketika karakter mereka masih labil, pengaruh masyarakat di luar sekolah akan mudah mempengaruhi pikiran, sikap dan perilaku 
siswa. Jika hal itu terjadi, pendidikan karakter ideal yang dilaksanakan di sekolah tidak akan memberikan hasil yang signifikan. Jurang yang lebar antara kultur yang dikembangkan di sekolah dan kehidupan nyata di dalam masyarakat akan menciptakan kepribadian terbelah dan hipokrit bagi para generasi muda. Jika fenomena ini masih berlangsung, negara tidak akan mampu mengatasi berbagai persoalan moral dalam masyarakat dan pemerintahan sebab sumber persoalan yang berasal dari pendidikan tersebut tidak dapat diatasi.

Dalam hubungan ini, pertanyaan selanjutnya yang perlu dijawab adalah: bagaimana cara menjadikan lingkungan masyarakat dan keluarga sebagai lingkungan belajar yang kondusif. Sudah barang tentu pertanyaan ini tidak mudah untuk dijawab sebab menyangkut spektrum yang sangat luas yang berada di luar kewenangan manajemen sekolah. Atau lebih jelasnya pemerintah lah yang memiliki kewajiban utama untuk membangun masyarakat yang kondusif sebagai ruang pendidikan yang ideal bagi siswa. Pemerintah sebagai pemegang otoritas semestinya mampu membuat dan menegakkan peraturan perundangan sehingga dapat tercipta masyarakat yang diidamkan. Hingga sekarang pemerintah belum sepenuhnya berhasil menjadikan masyarakat sebagai sumber dan sekaligus ruang belajar yang ideal bagi siswa. Bahkan seringkali kehidupan di luar sekolah dikhawatirkan justru mengontaminasi kepribadian siswa.

Ketika lingkungan di luar sekolah justru menjadi antesenden terhadap upaya pendidikan di sekolah, maka keberadaan sekolah bording untuk menerapkan pendidikan karakter yang kaffah sangat diperlukan. Di sekolah bording ini para siswa dapat digembleng secara kaffah sehingga menjadi pemuda yang memiliki karakter yang kuat sebagaimana yang diidealkan dalam dunia pendidikan. Setelah lulusan mereka ditargetkan sudah memiliki kepribadian yang kuat sehingga ketika harus terjun ke dalam masyarakat mereka tidak terkontaminasi oleh berbagai racun jiwa yang berkembang di dalam masyarakat. Bahkan diharapkan para lulusan sekolah bording ini dapat mewarnai dan memperbaiki kehidupan masyarakat, bangsa dan negara.

Sudah barang tentu masyarakat tetap penting untuk dijadikan sebagai sumber pembelajaran untuk memberikan kesadaran kepada siswa. Di sekolah, para siswa diinternasilasi dan disosialisasi mengenai nilai-nilai kecintaan terhadap sesama manusia, penghormatan kepada orang tua dan orang yang lebih tua, penanaman rasa cinta kepada tanah air dan cinta kepada bangsa Indonesia, keprihatinan terhadap kesejahteraan dan keadilan dalam 
masyarakat dan sebagainya sehingga diharapkan ketika lulus dari sekolah bording mereka menjadi pelita dalam masyarakat. Demikian juga sekolah harus membangun komunikasi yang baik dengan orang tua siswa melalui berbagai kegiatan yang diagendakan. Tidak kalah penting, sekolah juga bisa menjadikan masyarakat sebagai laboratorium untuk peningkatan kualitas karakter siswa, misalnya dengan pemagangan pada masyarakat miskin, panti asuhan, museum, dan sebagainya.

Sudah barang tentu perekayasaan masyarakat agar menjadi lingungan belajar yang kondusif tidak harus dilakukan oleh pemerintah. Ketika pemerintah belum sepenuhnya mampu melakukan itu, maka peran masyarakat melalui lembaga kemasyarakat juga sangat diharapkan. Dalam hal ini peran lembaga dakwah menjadi sangat penting. Lembaga dakwah seperti NU, Muhammadiyah, LDII, dan sebagainya mestinya bisa mengambil tanggungjawab ini. lembaga dakwah perlu mengoptimalkan perannya untuk menjadi benteng moral generasi muda dalam menghadapi tantangan dampak destruktif dari globalisasi.

Melalui jalinan hubungan baik antara sekolah bording dengan orang tua masyarakat, pihak sekolah bisa menawarkan program-program kepada orang tua melalui pengkajian nilai-nilai moral dan/ atau keagamaan. Dengan demikian sekolah pewrlu mengembangkan kegaitan 'pelayanan' kepada orang tua murid. Jika keluarga sebagai inti dari masyarakat sudah memahami dan memprakteknakan nilai-nilai luhur secara kaffah, maka dengan sendirinya secara evolusioner masyarakat juga akan mampu membangun budayanya yang sangat kondusif untuk lingkungan pendidikan dan sekaligus menghilangkan atau setidaknya mengurasi potensi lahirnya manusia yang berkepribadian ganda atau manusia hipokrit.

Namun catatan yang harus digarisbawahi adalah bahwa apapun jenis lembaga kemasyarakatan itu dan apapun program yang dilaksanakan, mereka tetap harus memiliki kimitmen total dalam konteks NKRI dan keindonesiaan.

\section{Penutup}

Dari uraian di atas dapat diambil beberapa poin penting, yaitu:

1. Pembangunan karakter bangsa merupakan sesuatu yang tidak bisa ditawar-tawar dalam rangka untuk memperbaiki krisis moralitas kebangsaan yang terjadi dewasa ini. Pendidikan karakter di sekolah merupakan salah satu upaya untuk pembangunan karakter keseluruhan.

2. Mengingat akar persoalah karakter bangsa bersumber pada kepribadian yang terbelah yang bermula dari adanya gap antara dunia pendidikan di sekolah 
dan dunia nyata dalam masyarakat maka diperlukan suatu sistem pendidikan yang kaffah yang mampu menciptakan manusia dengan kepribadian dan karakter yang utuh.

3. Di samping itu pendidikan yang kaffah juga perlu diiringi dengan upaya pemerintah untuk menciptakan dan menegakkan hukum dalam masyarakat yang merefleksikan nilai luhur budaya dan karakter bangsa sebagaimana yang telah dirumuskan oleh kemendikbud.

4. Model sekolah bording dengan penerapan pendidikan budaya dan karakter bangsa secara kaffah dapat dijadikan sebagai alternatif untuk mencetak generasi muda yang memiliki karakter yang diidealkan berdasarkan Pancasila dan nilai luhur budaya bangsa.

\section{Daftar Pustaka}

Ballard, Martin. 1971. New Movements in the Study and Teaching of History. Bloomingtob: Indiana University.

Birc, Anthony. 1989. Nationalism and National Integration, London: Unwin Hyman.

http://www.theceli.com/dokumen/ produk/1961/22-1961.htm

(http://en.wikipedia.org/wiki /Holistic_education)

Makmur, Djohan. 1993. Sejarah Pendidikan di Indonesia zaman Penjajahan (Jakarta: Depdikbud, 1993).
Masruki, 2010. "Model Pembelajaran Pendidikan Karakter", makalah disampaikan pada Seminar Nasional "Aktualisasi Fungsi Arsip sebagai Simpul Integrasi Nasional dalam Pembangunan Karakter Bangsa", Kerjasama Arsip Nasional Republik Indonesia (ANRI), Magister Ilmu Sejarah Program Pascasarjana Universitas Diponegoro, dan Masyarakat Sejarawan Indonesia (MSI) Cabang Jawa Tengah (Semarang: 25 Mei 2010).

Nasution, S. 1983. Sejarah Pendidikan Indonesia (Jakarta: Bumi Aksara).

Sjamsuddin, Hellius. 1993. Sejarah Pendidikan di Indoensia Zaman Kemerdekaan (1945-1966) (Jakarta: Depdikbud).

Stapel, F.W. 1938. Geschiedenis van Nederlandsch-Indië V. Amsterdam: Joost van den Vondel.

Sulistiyono, Singgih Tri. 2012. "Pendidikan Sejarah dan Pembangunan Karakter Bangsa", Makalah disajikan dalam Seminar nasional Pendidikan Karakter Bangsa (Ternate: Arsip Nasional republik indonesiaPemerintah Provinsi Maluku Utara). Zubaidi, 2011. Desain Pendidikan Karakter (Jakarta: Prenada Media, 2011). Buku pedoman pengembangan pendidikan budaya dan karakter bangsa kementerian pendidikan nasional badan penelitian dan pengembangan pusat kurikulum jakarta, 2010. 